\title{
Survival after liver transplantation for hepatitis C is unchanged over two decades in Canada
}

\author{
Kymberly DS Watt MD ${ }^{1}$, Kelly W Burak MD FRCPC ${ }^{2}$, Marc Deschênes MD³, Les Lilly MD4, Denis Marleau MD ${ }^{5}$, \\ Paul Marotta MD FRCPC ${ }^{6}$, Andrew Mason MD ${ }^{7}$, Kevork M Peltekian MD ${ }^{1}$, Eberhard Renner $\mathrm{MD}^{8}$, \\ Eric M Yoshida MD MHSc FRCPC FACP ${ }^{9}$, for the Canadian Transplant Hepatology Outcomes Research Network
}

\begin{abstract}
KDS Watt, KW Burak, M Deschênes, et al; for the Canadian Transplant Hepatology Outcomes Research Network. Survival after liver transplantation for hepatitis $\mathrm{C}$ is unchanged over two decades in Canada. Can J Gastroenterol 2008;22(2):153-154.
\end{abstract}

\begin{abstract}
Allograft failure secondary to recurrence of hepatitis $\mathrm{C}$ virus (HCV) infection is the most common cause of death and retransplantation among recipients with HCV infection. It has been suggested that patients transplanted for HCV have had worse outcomes in more recent years than in previous years (the 'era effect'). A Canadian transplantation registry database was analyzed to determine the outcomes of patients transplanted over the years for HCV. The results of the present analysis of 1002 patients show that the 'era effect' was not seen in liver transplantation recipients with HCV in Canada, because no survival difference was noted based on the year of transplantation. All groups had overall two-year and five-year survival rates of $76 \%$ to $83 \%$ and $69 \%$ to $72 \%$, respectively. The present study's national results prove continued benefit to transplantation of HCV patients.
\end{abstract}

Key Words: Era effect; Hepatitis C; Survival; Transplantation
La survie après une greffe du foie secondaire à l'hépatite $\mathrm{C}$ n'a pas changé depuis vingt ans au Canada

L'échec de l'allogreffe secondaire à une récurrence de l'infection par le virus de l'hépatite $\mathrm{C}(\mathrm{VHC})$ est la principale cause de décès et de nouvelle greffe chez les receveurs atteints d'une infection par le VHC. On a postulé que l'issue des patients ayant reçu une greffe en raison d'un VHC était plus négative ces dernières années que par le passé (« l'effet de l'époque »). Les auteurs ont analysé une base de données des registres canadiens des greffes pour déterminer l'issue des patients qui avaient reçu une greffe en raison du VHC au fil des ans. Les résultats de la présente analyse de 1002 patients révèlent que «l'effet de l'époque » ne s'applique pas chez les receveurs d'une greffe du foie atteints du VHC au Canada, car les auteurs n'ont remarqué aucune différence sur la durée de survie d'après l'année de la greffe. Tous les groupes présentaient un taux de survie global de $76 \%$ à $83 \%$ au bout de deux ans et de $69 \%$ à $72 \%$ au bout de cinq ans. Les résultats nationaux de la présente étude démontrent les bienfaits continus de la greffe pour les personnes atteintes du VHC.
$\mathrm{R}_{\mathrm{h}=\mathrm{e}}^{\mathrm{e}} \mathrm{de}$ ecurrent hepatitis $\mathrm{C}$ virus (HCV) infection is an Achilles' Reel of liver transplantation. Allograft failure secondary to recurrence of $\mathrm{HCV}$ is the most common cause of death and retransplantation among recipients with $\mathrm{HCV}$ infection. Often quoted throughout the medical literature is the increased fibrosis progression, as well as worse post-transplant graft and patient survival, of HCV patients who were transplanted in more recent years (often referred to as the 'era effect' or 'Berenguer effect', for the data published by Berenguer et al in 2000 and 2002 [1,2]). Efforts to discern causes for these worse outcomes has led to considerable change to immunosuppression regimens and, potentially, organ allocation in these patients. This, among other data, has also led to concern and speculation on the utility of transplantation in these individuals. Until recently, it was unclear whether this 'era effect' was reproducible in other centres or other countries. In the past few months, an analysis of the United Network of Organ Sharing suggested unchanged survival over the years for $\mathrm{HCV}$ patients post-transplant but improved survival for non-HCV patients over the same time frame (3). We have analyzed a Canadian transplantation registry database (4) to determine the outcomes of patients transplanted over the years for HCV.

\section{METHODS}

The Canadian Transplant Hepatology Outcomes Research Network performed an evaluation of the national liver transplant registry database. One thousand two patients who were transplanted for HCV-related diseases over 16 years were analyzed. To ensure accurate results, all transplantation centres in

${ }^{1}$ Division of Gastroenterology, Department of Medicine, Dalhousie University, Halifax, Nova Scotia; ${ }^{2}$ University of Calgary Liver Unit, Calgary, Alberta; ${ }^{3} \mathrm{McGill}$ University Health Centre, Montreal, Quebec; ${ }^{4}$ University of Toronto, University Health Network Liver Transplant Program, Toronto, Ontario; ${ }^{5}$ St. Luc Hospital, Centre Hospitalier de l'Université de Montreal, University of Montreal, Montreal, Quebec; ${ }^{6}$ Division of Gastroenterology, Department of Medicine, University of Western Ontario, Liver Unit, London Health Sciences Centre, London, Ontario; ${ }^{7}$ Division of Gastroenterology, Department of Medicine, University of Alberta, Edmonton, Alberta; ${ }^{8}$ Section of Hepatology, Department of Internal Medicine, University of Manitoba, Health Sciences Centre, Winnipeg, Manitoba; ${ }^{9}$ Division of Gastroenterology, Department of Medicine, University of British Columbia, Vancouver, British Columbia

Correspondence: Dr Kymberly Watt, Mayo Clinic, 200 First Street Southwest, Rochester, Minnesota 55905, USA. Telephone 507-266-7054, fax507-266-1856,e-mail watt.kymberly@mayo.edu

Received for publication June 8, 2007. Accepted September 18, 2007 


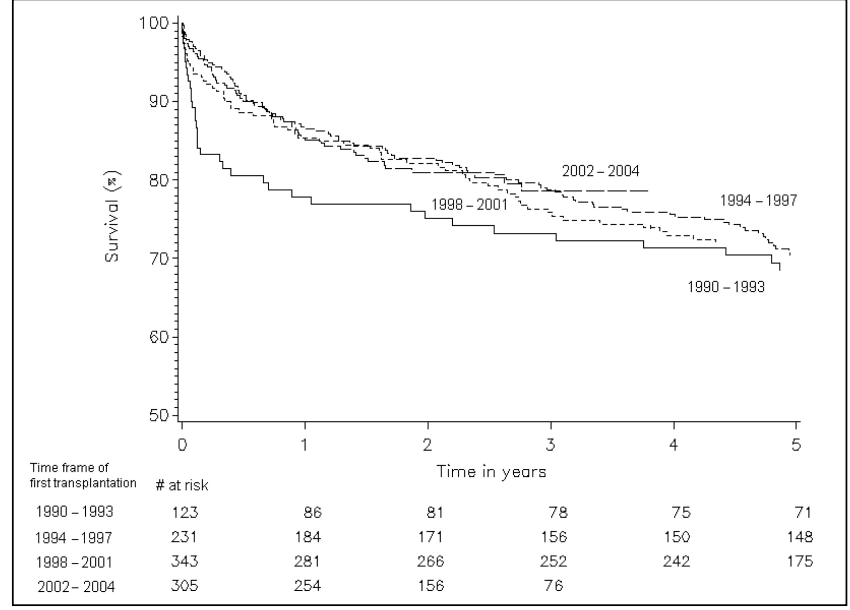

Figure 1) Kaplan-Meier post-transplant survival curves for hepatitis $C$ virus patients. Data from reference 3

Canada updated the registry database with current survival assessments of all patients transplanted for HCV-related liver disease since 1990, with follow-up data until 2006 (3). Unfortunately, the Canadian Organ Replacement Register is only a registry database; thus, no donor or recipient characteristics were available to analyze for risk factors associated with outcomes. All patients with a diagnosis of $\mathrm{HCV}$ were included in the study population. Only primary transplants were analyzed, which excluded patients receiving a retransplant. The post-transplant survival rate of all patients with $\mathrm{HCV}$ who were transplanted between 1990 and 1993, 1994 and 1997, 1998 and 2001, and 2002 and 2004 were analyzed. KaplanMeier survival curves were generated (Figure 1). Because of the database restrictions, categorizing for cause of death was not possible.

\section{RESULTS}

One thousand two HCV-positive patients were analyzed for outcomes. These patients represented all patients transplanted for HCV in Canada. There was no survival difference for the cohort of HCV patients based on year of transplantation (Figure 1). The two- and five-year survival rates were similar in all groups analyzed. The one-year survival rate of patients who underwent transplantation between 1990 and 1993 was lower than in other years ( $78 \%$ versus $85 \%)$, but this difference was not statistically significant (Table 1). For patients surviving the first year after transplantation, the survival curves were indistinguishable. These survival rates were no different from the general transplanted population survival rates over the same time frames (graph not shown). Statistically significant improvement in one-year survival was noted in the general transplant population (Table 1) in contrast to the HCV population, in which only a trend toward improvement in survival was noted, largely due to worse survival in the 1990 to 1993 cohort. However, overall one-year survival for the HCV population was not statistically different from the general population $(84.8 \%$ versus $85.7 \%, \mathrm{P}=0.65)$.

\section{TABLE 1}

Kaplan-Meier estimates of the one-year survival rates of liver transplantation patients with the hepatitis $C$ virus (HCV) compared with patients in the general transplant population

\begin{tabular}{lcc}
\hline & \multicolumn{2}{c}{ One-year patient survival, \% } \\
\cline { 2 - 3 } Time frame & General population & HCV patients \\
\hline 1990 to 1993 & 79.5 & 77.9 \\
1994 to 1997 & 85.3 & 85.4 \\
1998 to 2001 & 86.4 & 86.5 \\
2002 to 2004 & 89.0 & 85.1 \\
\hline
\end{tabular}

Log-rank test $P$ value $<0.0001 \quad(P=0.0812)$

\section{DISCUSSION}

The results of our analysis of 1002 patients show that the 'era effect' was not seen in liver transplant recipients in Canada. Thus, we were unable to confirm previously published data of worsening outcomes for patients transplanted for HCV over time. It is likely that the absence of the 'era effect' in Canada is related to a number of factors, including an absence of change in donor age in Canada over the years (4). A recently published analysis of the United Network of Organ Sharing database also suggested no difference in patient survival over time in HCV patients. They also noted no improvement in $\mathrm{HCV}$ patient survival over the years, which was in contrast to the improvement in the survival of non-HCV patients who were transplanted during the same time intervals (3). We found a similar result when comparing one-year survival of HCV patients over two decades with that of the general transplant population.

The finding of similar outcomes does not negate the ongoing problem of recurrent HCV and progressive liver disease and dysfunction related to the virus, nor does it address the issue of more rapid fibrosis over these same years. The present paper simply supports the concept that published data may not be transferable among programs and countries. Our national results do prove a continued benefit of transplantation in these patients, because the outcomes are quite good (five-year posttransplant survival rate, higher than 70\%). It remains unclear whether this patient population would benefit from different immunosuppression protocols or organ allocation policies, but those decisions should not be based on presumed worse outcomes in recent years.

\section{REFERENCES}

1. Berenguer M, Ferrell L, Watson J, et al. HCV-related fibrosis progression following liver transplantation: Increase in recent years. J Hepatol 2000;32:673-84

2. Berenguer M, Prieto M, San Juan F, et al. Contribution of donor age to the recent decrease in patient survival among HCV-infected liver transplant recipients. Hepatology 2002;36:202-10. (Erratum in 2003;37:489).

3. Thuluvath PJ, Krok KL, Segev DL, Yoo HY. Trends in post-liver transplant survival in patients with hepatitis C between 1991 and 2001 in the United States. Liver Transpl 2007;13:719-24.

4. Canadian Institute for Health Information. Canadian Organ Replacement Register. <http://secure.cihi.ca/cihiweb/ dispPage.jsp?cw_page $=$ services_corr_e $>$ (Version current at January 18, 2008). 


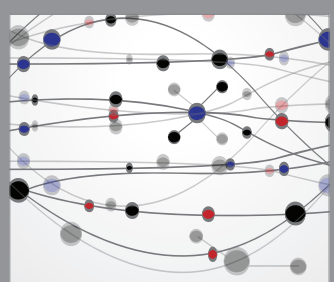

The Scientific World Journal
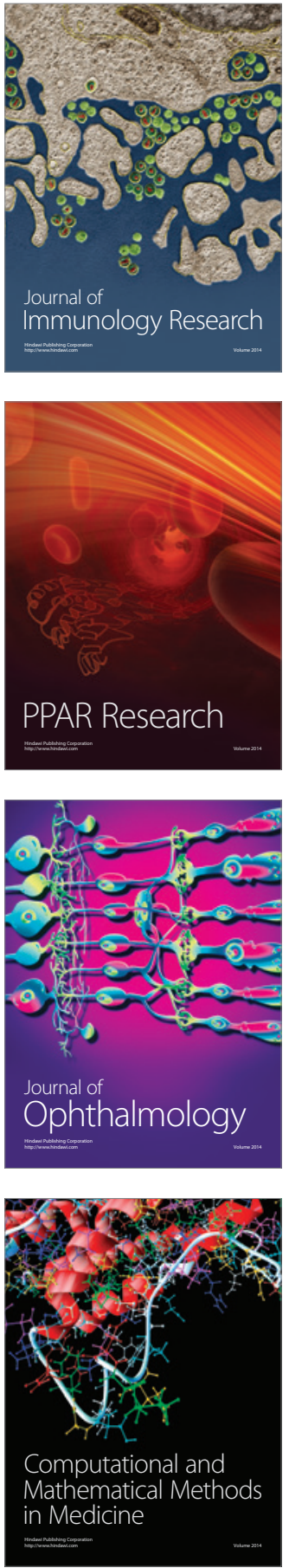

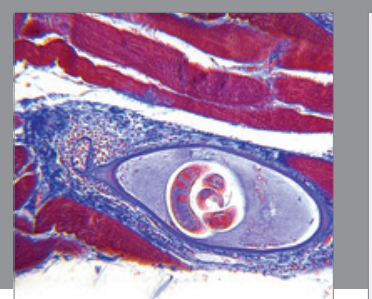

Gastroenterology Research and Practice

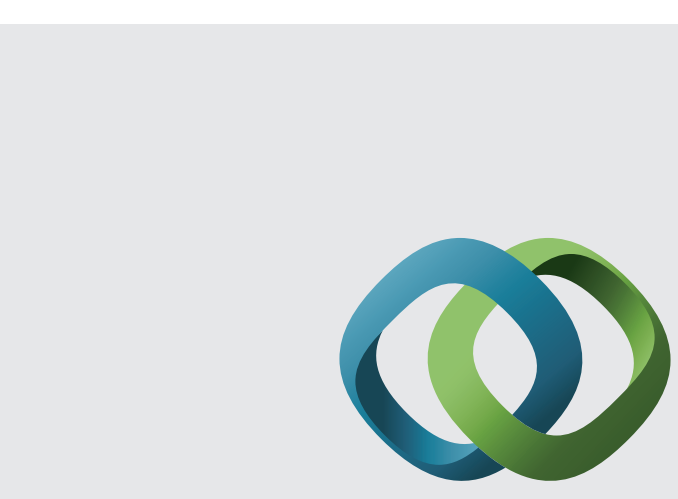

\section{Hindawi}

Submit your manuscripts at

http://www.hindawi.com
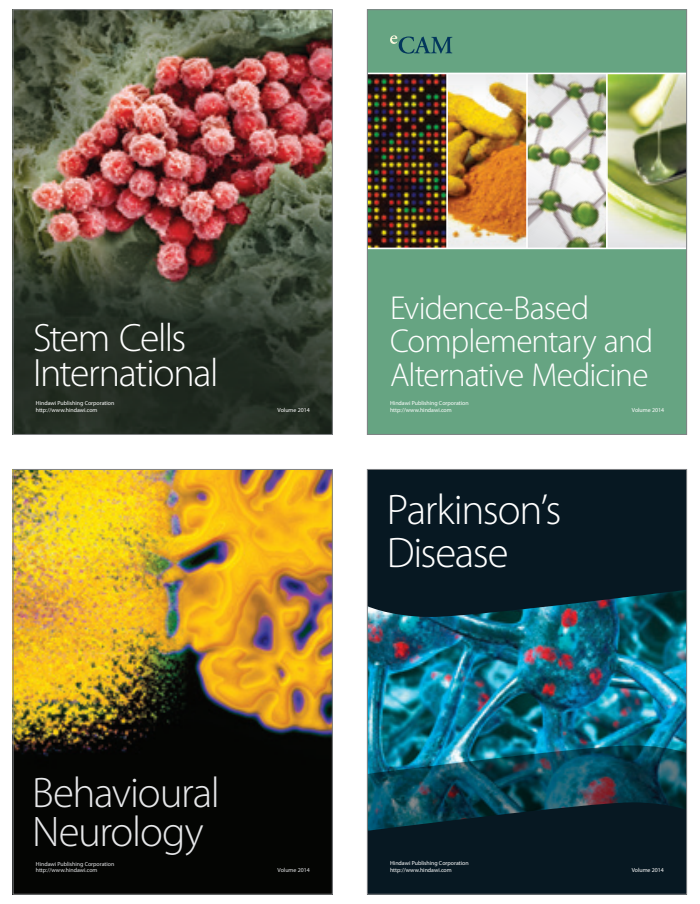
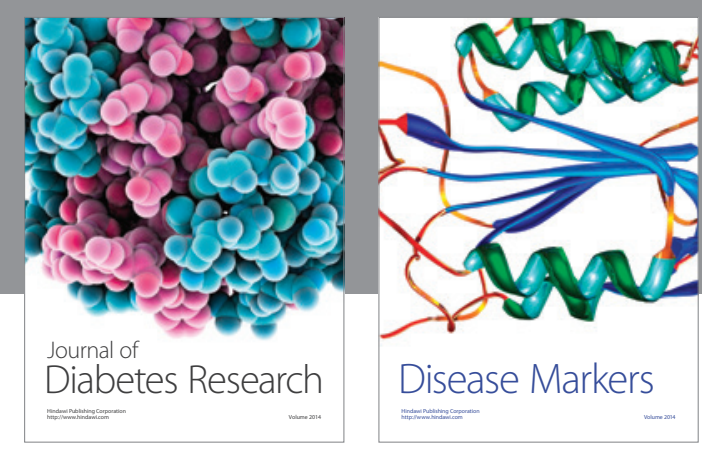

Disease Markers
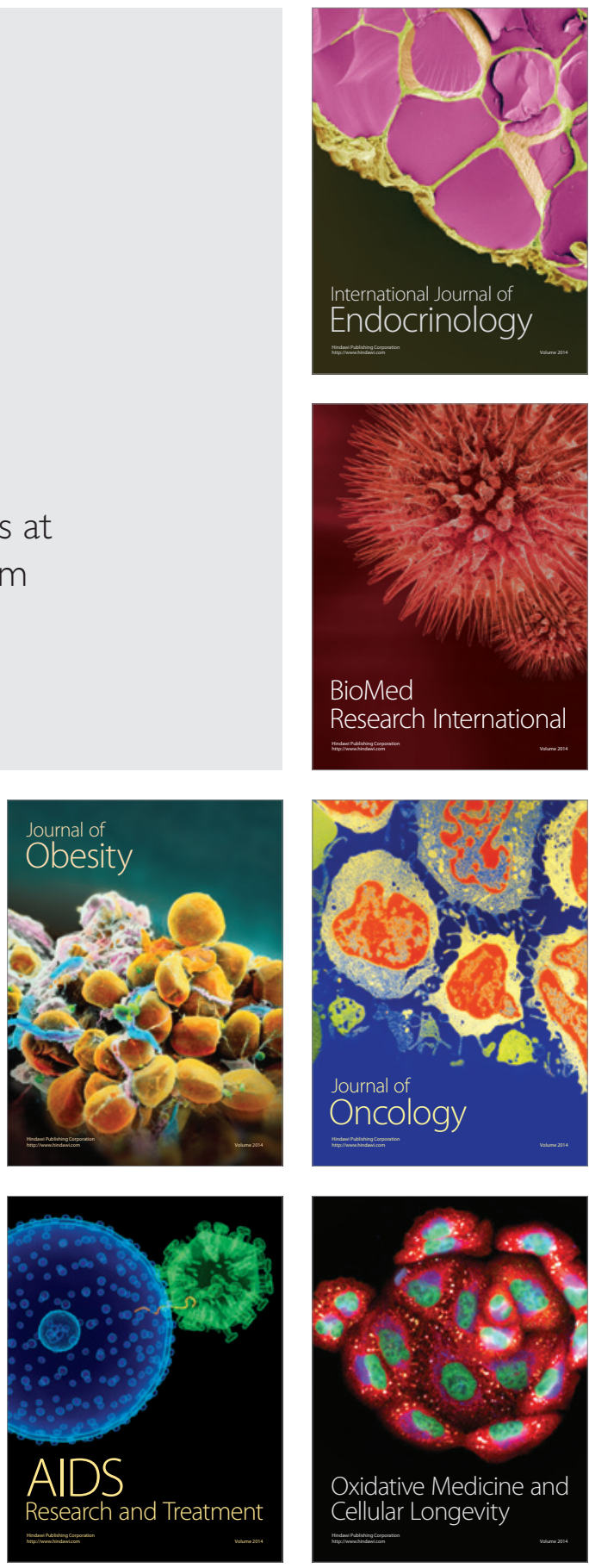